\title{
LAPAROSCOPIC VERSUS OPEN COLECTOMY: A RETROSPECTIVE OUTCOME OF 30 CONSECUTIVE PATIENTS
}

By

\author{
Ahmed Samir Abd El-Kader Ali, Osama Osman Ali Khalil and Ahmed \\ Ibrahim Shehata Kawashty
}

Department of General Surgery, Faculty of Medicine, Al- Azhar University, Cairo, Egypt

Corresponding author: Ahmed Samir Abd El-Kader Ali,

Mobile: (+20) 01116989971, (+2) 01050156660,E-mail: dr.ahmed_samir@yahoo.com

\begin{abstract}
Background: Colorectal cancer is one of the most common cancers in the developed world. Surgical removal of the primary tumor with adequate margins and lymphadenectomy provide the best chance of longterm disease-free and overall survival.

Objective: To detect the use of laparoscopy and its value in colectomy in comparison with open methods of colectomy as a treatment of early colorectal diseases.

Patients and methods: This was a retrospective study on 30 consecutive patients suffering from colorectal diseases specially operable colorectal cancers, an age of at least 16 years either elective or urgent surgery during the period from1/1/2015 to $1 / 1 / 2020$. Fifteen patients were operated upon by laparoscopic technique, and the other 15 patients were operated upon by open technique. Both groups were evaluated for operative data and early postoperative outcome.

Results: For laparoscopic colectomy, oncological results were at least as good as those of open surgery with clear advantages have been demonstrated for the laparoscopic approach in term of decreased intra-operative blood loss, faster postoperative recovery, return of bowel function, decreased pain and decreased hospital stay.

Conclusion: Laparoscopic colon resection was a feasible and safe alternative to the open approach, with some short-term advantages.
\end{abstract}

Key words: Laparoscopy, colectomy, colon cancer, rectal cancer.

\section{INTRODUCTION}

Standard oncologic surgery consists of en bloc bowel resection with appropriate proximal and distal resection margins and more than 12 harvested lymph nodes (Baxter et al., 2015).

The use of laparoscopic colectomy for colon cancer is an acceptable treatment not only for early colon cancer, but also for advanced cases because of its oncological safety and feasibility (Lacy et al., 2012).

The laparoscopic colectomy showed comparable oncologic results to the open colectomy group and even better survival rates in the patients with stage III disease. These results were later confirmed on long term follow-up (Lacy et al., 2018).

The laparoscopic approach for colon resection is widely accepted, but its 
definitive role in rectal tumors is still controversially debated due to technical difficulties and missing long-term results. Tumor size and volume and pelvic dimensions may influence intraoperative and/or immediate outcome. Furthermore, the good exposure of the pelvic cavity by laparoscopy and the magnification of anatomical structures seem to facilitate pelvic dissection (Künzli et al., 2010).

The aim of the present work was to compare between laparoscopic-assisted colectomy and open colectomy for colorectal diseases as regard to short- term outcome.

\section{PATIENTS AND METHODS}

This study was a retrospective study on 30 patients suffering from colorectal diseases specially operable colorectal cancers (stage I-W), an age of at least 16 years either elective or urgent surgery admitted in Al-Azhar University Hospitals during the period from January 2015 to January 2020. A written informed consent was obtained from every subjects of the study, and the study was approved by the Ethics Committee of Faculty of Medicine, Al-Azhar University. Fifteen patients (group A) were operated upon by laparoscopic-assisted technique in which the colon dissection and freely mobilization was done, then it was withdrawn through an extension of port site at the umbilicus and the colon came out of the wound easily. The resection of a segment of the colon, and the anastomosis are accomplished extra corporeally using a staplers then the completed anastomosis was dropped back into the abdominal cavity. The other 15 patients (group B) were operated upon by open technique. Certain parameters were assessed during the operative (amount of blood loss and operative duration) and early postoperative periods (lymph node harvest and recovery) for evaluating the procedure. The amount of blood loss is calculated by soaked gauze, every soaked gauze calculated by $150 \mathrm{cc}$ blood.

Analysis of data was done using SPSS (statistical program for the social science) with description of quantitative variables by $\mathrm{t}$ test or Mann-Whitney $\mathrm{U}$ test as mean $\pm \mathrm{SD}$, t-test was used to compare two groups as regard a quantitative variable and $\mathrm{P}$ value $<0.05$ was significant.

\section{RESULTS}

Amount of blood loss was higher among open group $(570.0 \pm 233.18 \mathrm{cc})$ compared to laparoscopic group (367.5 \pm $89.26 \mathrm{cc}$ ) with statistically significant difference between both groups as regard to intraoperative blood loss. Laparoscopic colectomy took more time $(135.3 \pm 25.4$ min) as compared to open colectomy
$(118.0 \pm 24.1 \mathrm{~min})$ with statistically significant difference between both groups. Lymph node harvest in laparoscopic colectomy $(14.30 \pm 2.03)$ was adequate as that of open colectomy (15.35 \pm 2.27$)$, with no statistically significant difference between both groups as regard to number of L.Ns (Table 1). 
Table (1): Comparison between both groups as regard to intraoperative blood loss, operative duration and number of L.Ns (Mean \pm SD)

\begin{tabular}{|c|c|c|c|}
\hline Groups & $\begin{array}{c}\text { Group A } \\
(\mathrm{N}=15)\end{array}$ & $\begin{array}{c}\text { Group B } \\
(\mathrm{N}=15)\end{array}$ & P value \\
\hline Blood loss $(\mathrm{ml})$ & $367.5 \pm 89.26$ & $470.0 \pm 233.18$ & 0.010 \\
\hline Time $(\mathrm{min})$ & $220.3 \pm 25.4$ & $203.0 \pm 24.1$ & 0.066 \\
\hline L.N number & $14.30 \pm 2.03$ & $15.35 \pm 2.27$ & 0.193 \\
\hline
\end{tabular}

There was a statistically significant difference between both groups as regard to postoperative ileus $(3.90 \pm 0.79$ days in laparoscopic, $4.55 \pm 0.76$ days in open colectomy), and significant difference as regard to parenteral analgesia $(2.55 \pm 0.83$ days in laparoscopic, $4.20 \pm 0.89$ days in open colectomy), and hospital stay (6.5 \pm 1.73 days in laparoscopic, $11.20 \pm 2.48$ days in open colectomy) (Table 2).

Table (2): Comparison between both groups as regard to recovery (Mean \pm SD)

\begin{tabular}{|c|c|c|c|}
\hline Groups & $\begin{array}{c}\text { Group A } \\
(\mathrm{N}=15)\end{array}$ & $\begin{array}{c}\text { Group B } \\
(\mathrm{N}=15)\end{array}$ & P value \\
\hline Parameters & $3.90 \pm 0.79$ & $4.55 \pm 0.76$ & 0.029 \\
\hline Ileus duration (days) & $2.55 \pm 0.83$ & $4.20 \pm 0.89$ & $<0.0001$ \\
\hline Parenteral analgesia (days) & $6.5 \pm 1.73$ & $11.20 \pm 2.48$ & $<0.0001$ \\
\hline
\end{tabular}

\section{DISCUSSION}

Our results showed that blood loss was significantly lower in the laparoscopic group than in the open group. This finding was consistent with the results of Braga and his Colleagues (2012). There was significant difference in the operative time between patients undergoing laparoscopic and open colectomies. More operative time was needed for laparoscopic procedures with a median of $135 \mathrm{~min}$. for the laparoscopic group compared to 118 min. median time for the open group, and that was the same as noted by Ohtani and his Colleagues (2011), who reported that the operative duration for laparoscopic colorectal surgery was significantly longer than for open colorectal surgery.

This was also the observation of Gandy and his Colleagues (2014) as they stressed that operative times were longer for laparoscopic colorectal resections than for the equivalent open procedures, but he further hypothesized that these differences will decrease with increasing experience and are likely to reach equivalence.

Detailed pathological studies of the resected specimens revealed no statistically significant difference in the number of lymph nodes harvested and the adequacy of the margins during laparoscopic colon resections and their corresponding conventional counterpart attesting to the ability to fulfill the rationale of radical resections in both groups. A study documented available data for laparoscopic versus open colectomy showed that both procedures commonly yield about thirteen lymph nodes a finding that is in accordance with our findings (Stracci et al., 2015).

In our study, we used the ability to resume oral diet as an indicator of resolution of postoperative ileus. We found that there was a significant difference in the period needed to resume 
oral diet being less in the laparoscopic group. The same finding has been reported by Milson and his Colleagues (2011).

In this study, there was a statistically significant reduction of postoperative pain judged by the time patients needed to control their pain by parenteral analgesics between the open and laparoscopic groups. Gandy and his Colleagues (2014) emphasized that laparoscopic surgery has shown us that conventional large incisions can be more traumatic than the small one and contribute to adverse metabolic responses seen in the perioperative period.

There was a statistically significant decrease in hospital stay in cases having laparoscopic colorectal resections when compared to those undergoing open resections. We would contribute this to the longer period of postoperative ileus and control of postoperative pain with parenteral analgesics in the open group. Patel and Bergamaschi (2013) stressed that length of hospital stay may depend more on preoperative counseling, discharge criteria, social arrangements, patient's health literacy, or type of health system than the means of surgical access.

\section{CONCLUSION}

Laparoscopic colon resections were feasible technically with a comparable efficacy of resection of tumor bearing segments with its lymph nodal basin to the corresponding open standard colon resections. Furthermore, short term outcome findings of this study can be critically appraised as findings directly related to patient's acceptance of the technique. The most valuable short term advantage for laparoscopic colon resection was the hospital stay time and less need to parenteral analgesia.

\section{REFERENCES}

1. Baxter NN, Virnig DJ, Rothenberger DA, Morris AM, Jessurun $J$ and Virnig BA (2015): Lymph node evaluation in colorectal cancer patients: a population-based study. J Natl Cancer Inst., 97: 219-25.

2. Braga M, Vignali A, Gianotti L Zuliani W, Radaelli G, Gruarin P, Dellabona $P$ and Di Carlo $V$. (2012): Laparoscopic versus open colorectal surgery: a randomized trial on short-term outcome. Ann Surg., 236:759-767.

3. Gandy CP, Kipling RM and Kennedy RH (2014): Laparoscopic colorectal surgery .In: Recent advances in Surgery 27. Johnson C. and Taylor L (Eds). Pbl. Royal Society of Medicine press, London; pp. 123-136.

4. Künzli BM, Friess $H$ and Shrikhande SV (2010): Is laparoscopic colorectal cancer surgery equal to open surgery? An evidence based perspective. World $\mathrm{J}$ Gastrointest Surg., 2 (4): 101-108.

5. Lacy AM, Delgado S, Castells A, Prins HA, Arroyo V, Ibarzabal A and Pique JM. (2018): The longterm results of a randomized clinical trial of laparoscopy-assisted versus open surgery for colon cancer. Ann Surg., 248: 1-7.

6. Lacy AM, García-Valdecasas JC, Delgado S, Castells A, Taurá P, Piqué JM and Visa J. (2012): Laparoscopy-assisted colectomy 
LAPAROSCOPIC VERSUS OPEN COLECTOMY: A RETROSPECTIVE... 173

versus open colectomy for treatment of non-metastatic colon cancer: a randomised trial. Lancet, 359:22242229.

7. Milson JW, Hammerhofer KA, Bohm B, Fazio $V$ and Steiiger $E$ (2011): Prospective, Randomized Trial Comparing Laparoscopic vs. Conventional Surgery for Refractory Ileocolic Crohn's disease. Dis Colon and Rectum, 44(1):1-8.

8. Ohtani H, Tamamori Y, Arimoto Y, Zemon H, and DeNoto G (2011): A Meta-Analysis of the Short- and Long-Term Results of Randomized Controlled Trials That Compared Laparoscopy-Assisted and
Conventional Open Surgery for Colorectal Cancer. J Cancer, 2: 425434.

9. Patel NA and Bergamaschi $R$ (2013): Laparoscopy for diverticulitis. Surg Innov., 10(4): 177183.

10. Stracci F, Bianconi F, Leite $S$, Liso A, La Rosa F, Lancellotta V, van de Velde CJ and Aristei C (2015): Linking surgical specimen length and examined lymph nodes in colorectal cancer patients. Eur J Surg Oncol., 42(2):260-5. 


\section{استنئصال القولون باستخدام منظار البطن الجر احى مقارنة

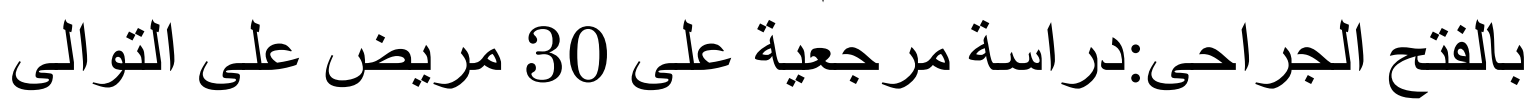
أحمد سمير عبدالقادر على, أسامة عثمان على خليل, أحمد ابراهيم شحاتة قوشتى قسم الجراحة العامة, كلية الطب, جامعة الأزهر, القاهرة, مصر

E-mail: $\underline{\text { dr.ahmed_samir@yahoo.com }}$

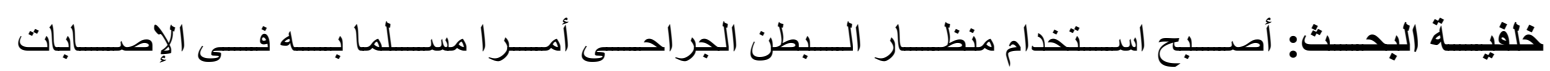

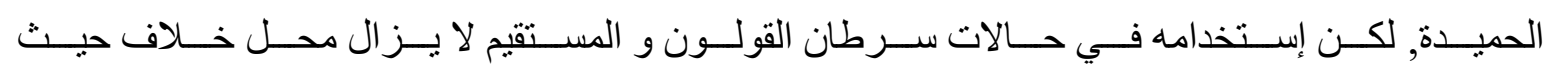

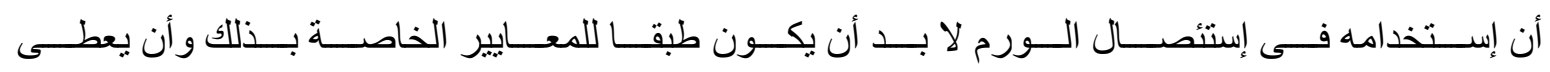

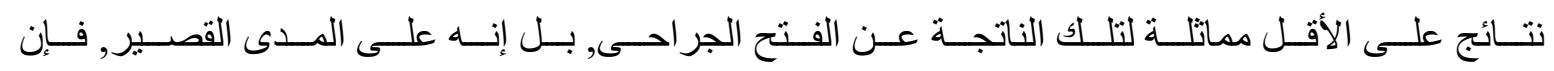
العديد من الدراسات أوضحت فو ائد منظار البطن عن الفتح الجراحى.

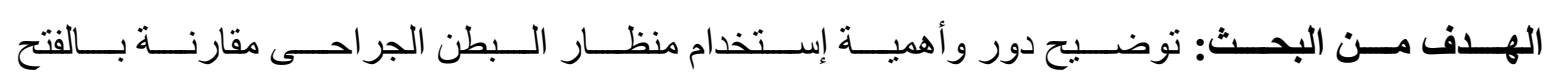

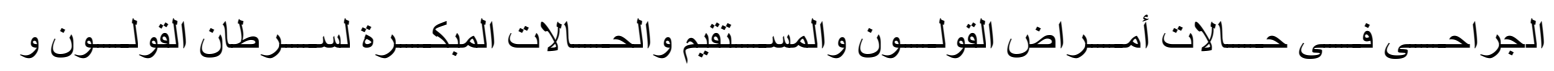
الدستقيم. - | (الجرا.

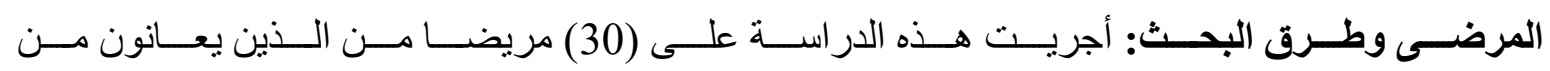

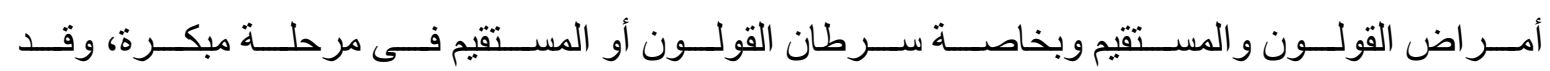

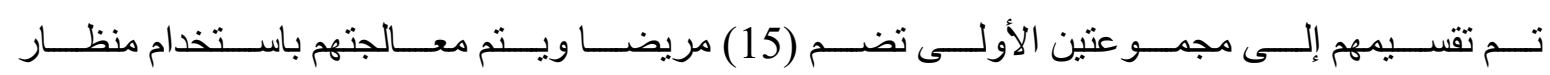
البطن الجراحي, والثانية تضم (15) مريضا وينم معالجتهم باستخدام الفتح الجر احى.

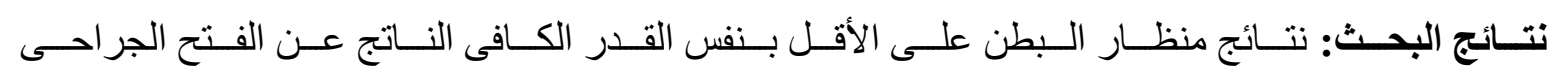

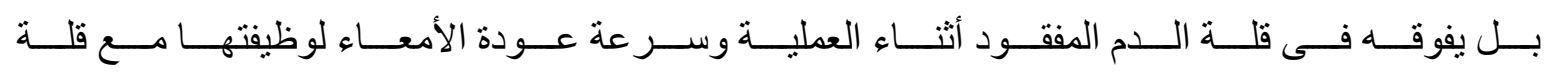
الإحساس بالألم بعد العملية وتقليل مدة الإقامة بالمستثفى.

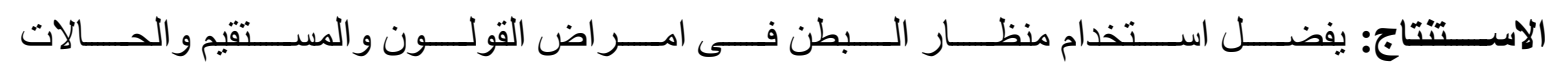
المبكرة لسرطان القولون والمستقيم إذا تو افرت الخبرة و الإمكانيات اللازمة لذلك. الكلمات الدالة: منظار البطن, استئصال القولون, سرطان القولون, سرطان المستقيه. 